\title{
Imaging biomarkers for malignant peripheral nerve sheath tumors in neurofibromatosis type 1
}

Neurology ${ }^{\circledR}$ 2020;94:504. doi:10.1212/WNL.0000000000008669

In the article "Imaging biomarkers for malignant peripheral nerve sheath tumors in neurofibromatosis type 1 ” by Ahlawat et al., ${ }^{1}$ first published online ahead of print August 8, 2019, the order of the histology slides in figure 4 should have appeared as in the revised figure below. The figure appears correctly in the September 10, 2019, issue. The authors regret the error.

\section{Reference}

1. Ahlawat S, Blakeley JO, Rodriguez FJ, Fayad LM. Imaging biomarkers for malignant peripheral nerve sheath tumors in neurofibromatosis type 1. Neurology 2019;93:e1076-e1084.

Figure 4 Histopathologic features of nerve sheath tumors

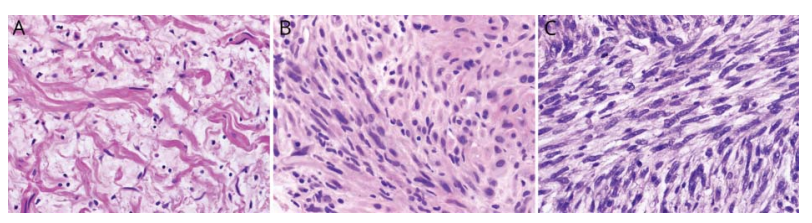

\section{Pregnancy decision-making in women with multiple sclerosis treated with natalizumab \\ I: Fetal risks}

\section{Pregnancy decision-making in women with multiple sclerosis treated with natalizumab \\ II: Maternal risks}

Neurology ${ }^{\circledR}$ 2020;94:504. doi:10.1212/WNL.0000000000008670

In the articles "Pregnancy decision-making in women with multiple sclerosis treated with natalizumab: I: Fetal risks" by Portaccio et al. ${ }^{1}$ and "Pregnancy decision-making in women with multiple sclerosis treated with natalizumab: II: Maternal risks” by Portaccio et al., ${ }^{2}$ Dr. Amato's affiliations should have included:

Department NEUROFARBA, University of Florence, Italy

IRCCS Fondazione Don Carlo Gnocchi, Florence, Italy

The authors regret the error.

\section{References}

1. Portaccio E, Annovazzi P, Ghezzi A, et al. Pregnancy decision-making in women with multiple sclerosis treated with natalizumab: I: Fetal risks. Neurology 2018;90:e823-e831.

2. Portaccio E, Moiola L, Martinelli V, et al. Pregnancy decision-making in women with multiple sclerosis treated with natalizumab: II Maternal risks. Neurology 2018;90:e832-e839. 


\section{Neurology}

\section{Imaging biomarkers for malignant peripheral nerve sheath tumors in neurofibromatosis type 1}

Neurology 2020;94;504 Published Online before print February 26, 2020

DOI 10.1212/WNL.0000000000008669

This information is current as of February 26, 2020

\section{Updated Information \&} Services

References

Permissions \& Licensing

Reprints including high resolution figures, can be found at: http://n.neurology.org/content/94/11/504.1.full

This article cites 1 articles, 1 of which you can access for free at: http://n.neurology.org/content/94/11/504.1.full\#ref-list-1

Information about reproducing this article in parts (figures,tables) or in its entirety can be found online at:

http://www.neurology.org/about/about_the_journal\#permissions

Information about ordering reprints can be found online:

http://n.neurology.org/subscribers/advertise

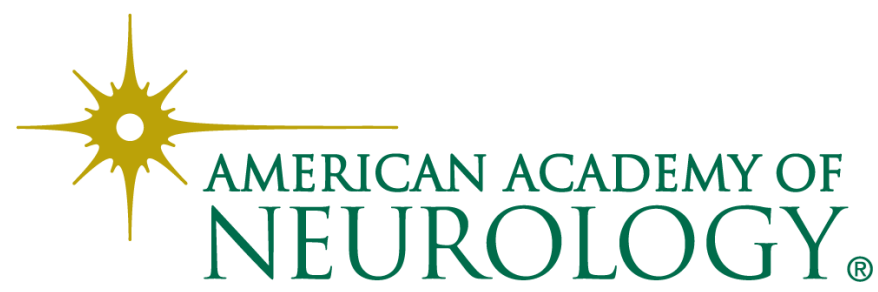

